\title{
The Performance of Mangupa Tradition in Angkola Custom, Medan, Indonesia
}

\author{
Akhiril Pane $^{1}$, Robert Sibarani ${ }^{2}$, Ikhwanuddin Nasution ${ }^{3}$, Muhammad Takari ${ }^{4}$ \\ 1,2,3,4 Universitas Sumatera Utara, Indonesia \\ pane55330@gmail.com
}

\begin{abstract}
The Angkola oral tradition of mangupa is as household advice by appealing to Allah SWT. This tradition is trusted by indigenous communities to restore the spirit to the body (paulak tondi tu badan). As the object of study is the performance analysis by using Duranti theory (2001: 14) with a view of a) performance, b) indexcality, and c) participation and theory of the performance. Finnegan (1991, 1992: 92-93) states that there are 3 elements such as: a) composition, a form that is composed, $b$ ) transmission, the selection process that will continue the oral tradition, and (3) the audience. The methods used are surveys, interviews with key informants, primary data source at the ceremony and secondary data by collecting field data, analyzing data. The result of the analysis of traditional Angkola data is divided into four components: a) Ceremonial place, b) Ceremonial time c) Traditional tools, d) Traditional leaders and participants. The transmission of customary philosophy: sangap, hamomora. and hamoraon. The audiences are all who attended the Angkola traditional wedding ceremony in the tradition of mangupa. The advice on mangupa consists of: 1) mangupa text using the name of Allah SWT, 2) mangupa texts of prayer and hope, 3) mangupa text of hope, and 4) mangupa text with philosophical Angkola custom.
\end{abstract}

Keywords

mangupa; anthropolinguistics, Angkola tradition decisions

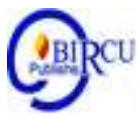

\section{Introduction}

Angkola custom individually is formed and supported mainly by the ethnic culture of Angkola. The tradition of mangupa as an inseparable part of the society users is believed to be the community users and as a very important sacred part, since the core of tradition is mangupase band as household life guide in the form of advice. The Angkola marriage ceremony is not determined by the size of the ceremony. The ceremony of mangupa is conducted because of having the essential values that continue to be guided until now.

The other factors that become the challenge for tradition of Angkola custom are: a) time consuming, b) redundant, c) religious dogmas which do not mix with the custom, d) simplifying the implementation of traditional Angkola ceremonies (traditional ceremony previously were held in seven days, three days, now it is held not more than one day), e) economic factors, expensive cost, and time effectiveness. These affects the simplification of the tradition (Amri, 2011: 212).

The strong responsibility of dalihan na tolu elements is always involved in every community affairs including those that will perform the marriage ceremony (siriaon) and the death ceremony (siluluton). According to Harahap (1993: 316-385) the stages of Angkola traditional marriage ceremonies consist of: 1) manganaekkon gondang; 2.) pajongjong mandera; 3) mangupa; 4) marbondong; 5) maralok-alok; 6) manortor; 7) mambaen goar; 8) mamanjangi ipon; 9) patuaekkon; 10) mangupa; 11) and others. 
The development of the modern age also supports a bit more began to eliminate and annihilate the oral tradition. One of the various oral traditions that are feared to lose the speakers is that the lesser the speakers understand the oral mangupa tradition of Angkola custom.

As one of the ceremonies trusted by Angkola community in SouthTapanuli, it is very important to be studied and conserved. The Angkola marriage ceremony consists of some stages: a) manganaekkon gondang; b.) pajongjong mandera; c) mangupa; 4) marbondong; e) maralok-alok; f) manortor; g) mambaen goar; h) mamanjangi ipon; i) patuaekkon; j) mangupa; k) and others. (Parsadaan Marga Harahap, 1993: 316-385).

Luhak Angkola is as one of the Bataknese culture that has differences with other Bataknese culture. Eventhough Luhak Angkola in general is religious Moslems who have high enough tolerance. But likewise, the Angkola indigenous people are still sensitive to the customs that govern their daily lives from the beginning.

The Angkola tradition is still used although the intensity of the use is rarely used, due to its many inhibiting factors, a) Islamic and Christian dogma that oppose the traditions, Angkola customs, b) limited financial factors, c) limited customary actors, however the customs are still used (Amri , 2017: 1). It is also interesting to describe and review the performance of mangupa traditional Angkola custom.

\section{Review of Literatures}

\subsection{Mangupa Tradition of Angkola Custom}

Tradition is something that is passed down from the heritage of the ancestors to the next generation in a relay descends performed by the indigenous communities that have become deeply entrenched the culture in life. Customs and traditions include the creation and work of human beings who have become convictions in regulating the social order of life. The oral tradition is a verbal message of statements reported from the past to present-day generations, possibly spoken or sung with or without music.

Furthermore, Esten (1999: 21) defines that tradition is a hereditary custom of a community based on the cultural values of the people concerned. Esten further affirms that tradition shows how members of society behave, whether in worldly life or on things of a supernatural or religious nature.

Tradition can be tangible goods or services, even the combination of the two. As a product, tradition can be said to be a product of the past. While as a service, tradition is an activity undertaken by the community, which type and way is certain. Such products and activities are passed on from one generation to the next. In the goods and services products are contained symbols and meanings and values and norms that also be passed along with the goods and services it contains.

Vansina (1985:1) states that the expression of oral tradition applies both to a process and to its product. The products are oral messages at least a generation old. The process is the transmission of such messages by word of mouth over the time until the disappearance of the message”. Meanwhile, Suparlan (2003:2) states that various habits that exist in Indonesia raises ethnic groups that have a diversity of cultures that each has uniqueness of its own.

Previously, mangupa procession is closely related to the understanding of the ancestors. Thus, its implementation is adapted to their beliefs then. However, now since the entry of Islam that is generally embraced by the ethnic community of Angkola, so that the implementation of mangupa tradition is adapted to Islamic norms. Therefore, his word of 
advice also uses the teachings of Islam and indigenous languages. Tradition custom or mangupa tondi dohot bodies implemented to restore and or strengthen the spirit and the body.

The mangupa ceremony aims to return tondi to the body and asks blessing from God Almighty to always survive, healthy, and cheap sustenance in life. The attempts to call tondi to the body are conducted by means of serving a set of materials (pangupa devices) and pangupa (pataupa hata wages), which are arranged systematically and carried out by various parties consisting of parents, kings and other parties customs.

\subsection{Mangupa Performance in Anthropolinguistics Concept}

Antropological linguistics is that sub-field of linguistics which is concern with the place of language in its wider social and cultural context, its role in forging and sustaining cultural practices and social structures. As such, it may be seen to overlap with another sub-field with a similar domain, sociolinguistics, and in practice this may indeed be so, (Foley, 2003:3).

The anthropolinguistic studies on oral tradition begin with non-verbal elements. The structure and formulas of verbal and nonverbal elements of oral tradition can be explained through the understanding of the structure of the text and its context so that the understanding of forms also becomes an understanding of oral tradition's performance. In other words, the anthropolinguistics studies the texts and the performance of oral tradition within the framework of anthropology, the anthropolinguistic assessment according to Duranti (2001: 14) needs to approach with a) performance, b) indexcality, and c) participation.

The performances according to Finnegan (1992: 92-93) are all the spheres of markers of supporters in the social life on ethnic frames containing the aesthetic values that can be interpreted, from the object of the study of the tradition, the sign system and the signifiers of the utterance such as nods, dialogue, proxemics, by looking at the elements that are used on the activity. Regarding to the performances on performing arts and oral literature, Finnengan. (1991) states that there are 3 elements such as: a) composition, a composed form, b) transmission, a selection process that will continue the oral tradition, and (3) the audience of the show.

In the performing arts, seeing the concept of performance with the concept of performance on customs is as a tradition that has been entrenched as a public trust. Of course it needs to be a consideration of concepts that are in line with the object of the study. Here sometimes lies the occurrence of coercion of a theory or a more linear study in separating the art as performances and as a trust.

\section{Research Methods}

The research methodology aims to analyze the research objects in a systematic and organized oral tradition of mangupa by using qualitative methods with ethnographic approach based on the perspective of traditional community owners. Spradley (2007: 4) cites the view put forward Malinowski that the goal of ethnography is to understand the point of view of the existing indigenous population, his relationship with life, to get his view of his world. Further, Spradley (2007: 4) says ethnography not only studies the community but more than that ethnography learns from the community.

Traditional mangupa research is carried out procedures and methods to obtain information ethically from the informants by conducting interview and observation methods. McMillan and Schumacher (2001: 395-396) call this social reality in qualitative research as: "Qualitative research describes and analyzes people's individual and collective social actions, beliefs, thoughts, and perceptions. The researcher interprets phenomena in term of meanings people bring to them. Interactive qualitative research is inquiry in which the researcher 
collects the data face to face situations by interacting with selected persons in their settings (field research). Reality as multilayer, interactive, and a shared social experience interpreted by individuals."

The data collection method in the opinion of Sudaryanto (1993) uses social survey techniques by conducting structured observation interviews, content analysis, and texts, and techniques of analysis of traditional mangupa activities. The mangupa data collection step as the data in this study is expected to represent the oral tradition of mangupa in Angkola society in general, with the data analysis steps are: a) Transcription of the data from the recording data is translated into Indonesian language, b) classification of data and data analysis. (b) Collecting, sorting the data, c) Classifying the data, d) synthesizing, e) Making endeavors as well as making its index, f) Recording, sorting the data, g) Saidel in Moleong (2005: 248) ) creates some categories of data and find the patterns and the relationships as well as make findings.

\subsection{Wedding Ceremony of Angkola Custom}

The marriage ceremony with the second tier (manonga pertengahan) is a goat. Then after suhut sapanggadongan (host with his extended family) convey the intent and purpose (andung dohot holos), then responded by raja panusunan bulung after being asked by the rich. Next all the participants at the martahi ceremony give the same answer that is to receive and will succeed the marriage ceremony that usually speak in Angkola language Hamida manjagit aha sitta-sitta na di roha munu, mudah-mudahan nian saut dohot tulus sude karejo taon semoga Allah SWT meringankan langkah dan mengabulkannya, tai bope songoni harana di don dope oppui sian bagas godang hami sorahkan sude keputusanon tu ibana, harana ibana oppui do namalo mangattak mangetong, botima. The meaning is "We accept what is the intention stored in your heart (suhut) hopefully this marriage ceremony runs smoothly may Allah SWT meringan step and grant it, but even so because in the king king panususnan big bulung our heart submit this decision to the clever and wise."

The advice of parents to their children Jadi ma hamu na dua songon sira, inda lengkap perlagutan ta oni, sehingga di segala bentuk perkumpulan di masyarakat, di keluarga, di pekerjaan anggo inda disi hita hurang makna ni karejo $i$. The meaning is "You both are like salt. incomplete this meeting, so that in all forms of association in the community, in the family, and in the work if there is no us less meaning of the work."

Traditional marriage ceremony is as a series of traditional ceremonies that bind between the two bride that according to the rules of custom and religion. The traditional marriage ceremonies as horja siriaon are sacred things that are expected to happen once in a lifetime. The mangupa tradition gives advice to various elements of the transfer of natolu and customary figures, parents, kings of tradition and other customary parties. In the execution of mangupa traditions there is a difference in the tradition of carrying a pangupa of a buffalo with a goat. The use of pangupa a buffalo means to perform the horja godang which means that all marriage ceremonies must be executed, whereas if the pangupa is a goat becomes the eyes of the peak event only mangupa only.

The mangupa tradition of Angkola is divided into four components: a) Place of ceremony, b) Time of ceremony, c) Traditional tools, d) Traditional leaders and participants. The place and time of the customary marriage ceremony is Horja Manongadi, Jonggol Julu sub village, Arse Nauli Sub District, South Tapanuli, North Sumatetra Province which was held on 4 May 2014 between Hendri Junaidi Ritonga and Afrida Susanti Nasution, SH.

The tools and materials in the tradition of Mangupa are also called as pangupa. The pangupa material is a set of foodstuffs placed on the tampi (wide plate) which three strands of the tip of banana leaf (bulung tip) under it. As mentioned above, the pangupa materials 
that have been processed are: pira manuk na nihobolan (chicken egg), manuk (chicken), hambeng (goat), anduri (tampi) three tip bulung (banana leaves tip) sibonang manita (white rice called siribu-thousand), small fish (haporas and incur), goldfish, parmiakan ni manuk (chicken back), goat thigh, chicken thigh, three chicken eggs have been peeled (pira manuk na dihobolan) with a salt in the center, a goat's head, the pangupa is covered with a single tip bulung (banana tip), and a traditional cloth, abit godang (local blanket) as a cover of pangupa material.

The traditional king who leads the traditional ceremony of the Porang Pane Gelar Amansyah Pane, the leaders and participants of the mangupa tradition who convey hata pangupa, starting from: 1) the rich, 2) suhabolonan starts from the mothers and the bride, 3) kahanggi, 4) anak boru, 5) mora, 6) raja panusunan bulung.

\subsection{Philosophy of Traditional Transmission of Angkola Mangupa}

The traditional transmission of Angkola mangupa is as advice and life advice to the bride and groom Jagit bo tulang burangir on, jagit bo nantulang burangir sirara unduk sibontar adop-adop. Sataon so ra buruk, sabulan so ra malos. "Sumurdu burangirnami di hamu, di hananaek ni mata ni ari on." The meaning is "Accept this betel, red back and white front. A year will not rot, a month will not wither. We offer our betel to you, as the sun begins to rise." The phrases on the rarely used pangupa text in everyday language which has a symbolic meaning that a month's betel will wither.

Mangupa uses the traditional philosophy Maroban sangap dohot tua.Hamomora which means degrees, rich. The philosophical hamoraon is to seek for sustenance but the lawful. The transmission and inheritance of indigenous cultures that have cultural values are as the traditions with guidelines of community life containing wisdom, truth and ideas. In order the tradition of mangupa as philosophical can be understood by both the bride and bridegroom, some points are:

\section{a) Mangupa Texts with Philosophical Sangap}

The text has a philosophical meaning like Maroban sangap dohot tua which means: "Bringing the valor and dignity", Anso manaek ma tua which means "The advice goes up". Hamomora means degree, Hahorasan means health. Dohot, hagabean di hamu na niadopkon ni pangupa on which means: "And glory to you both". Jana anso saut dohot tulus na niparsinta ni rohanta $i$ " which means "To accomplish what we want." The words of hasangapon, glory, dignity, charisma, as the ultimate value give a strong impetus to achieve glory. The philosophical hasangapon as Honor and Glory will emerge from the bias of obtaining hagabeon and hamoraon because it can not be obtained by itself and hasangapon is reflected from the attitude and characteristics of the sleazy, just and wise. The characteristics of hasangapon as a bias of the charismatic attitude, so dignity and respectability would be meaningful to hasangapon if it has possessed a sleazy, just, and wise as the basic characteristic in the values of Hasangapon.

\section{b) Mangupa Text with Philosophical Hamoraon}

The philosophical hamoraon means wealth makes people become noble and respected. Hamoraon in everyday life that stands out established economic behavior. The philosophical hamoraon is to seek for sustenance but the lawful, mangupa texts containing advice to diligent and diligent attempt submitted by the raja bulung panusunan Dohot mambaen rasoki which means "To get sustenance" and reaffirmed with Sadoa mahita aso ro nian rasoki anak dohot parumaen which means "One prayer for the sustenance of the child and the son-inlaw". Then closed with Momo paccarion aso which means "Easy livelihood". The sustenance 
will be obtained if it has health it is expressed in text mangupa such as: Hahorasan which means health. The phenomenon seeking the sustenance for the community of Angkola continues to struggle and work hard to seek sustenance to achieve hamoraon. People associate a person's behavior with an established economy and then backed by good ethics.

\section{c) Mangupa with the philosophical Hagabeon}

The philosophical hagabeon is expressed in the sentences Hagabean di hamu na niadopkon ni pangupa on which means: "Glory to both of you in front of this pangupa". What is the philosophical meaning in the word hagabeon, why is this hagabeon often expressed by the tradition figures. Hagabeon, means having many offspring and longevity. In Angkola's saying "many children earn much sustenance", because the child is the pride and power that is able to work. The Angkola proverb Maranak sapulu pitu marboru sapulu onom. So a family who has 33 children means a formidable force to work but have good human resources as well. Long life in the concept of hagabeon is called saur matua bulung (like the deciduous leaves after old) on Angkola customs expression. As illustrated in the sentence "Hagabean di hamu na niadopkon ni pangupa on" which means: "Glory to you both in front of this pangupa". Then proceed with the pangupa sentence: "Anso manaek ma tua" which means the advice goes up. Jana anso saut dohot tulus na niparsinta ni rohanta $i$ which means "To accomplish what we want" and it concludes with Indahan parjamuan mambutongi tondi dohot badan munu which means "The rice in front of you this is the name of the feast that fills your heart and your body."

\subsection{Audience of Traditional Mangupa of Angkola}

Audiences in the tradition of mangupa haroan boru are the bride and groom. Besides the two brides, the tradition of mangupa haruan boru must be attended by Angkola-Saipirok traditional structure in South Tapanuli, namely Dalihan na Tolu is kahanggi, anak boru, and mora. Kahanggi suhut sihabolonan, a family group of Pane surnames. Anak Boru on the tradition of mangupa is the group that took the wife of the first party, whose surnames are Siregar. Mora who gives the wife to the first party whose surname is Ritonga.

The audiences in the tradition of mangupa are all present at the Angkola traditional wedding ceremony, namely: the two brides, na tolu (kahanggi, anak boru, and mora), pisang rahut, hatobangon, raja pamusuk, raja tording balok, raja panusunan bulung, ulemas (religious leaders), and from the elements of government.

\section{Discussion}

\subsection{Analysis of Traditional Performance of mangupa in Angkola Custom}

The pangupa materials are prepared so that it begins the execution of the mangupa tradition. The initial stage begins with the arrangement of the seated position adapted to its position in the custom of the dalihan natolu during the Mangupa tradition. The customary figures of the natolu transfers in the traditional court room and sit in accordance with their position on custom, then the pangupa material is lifted and brought into the customary courtroom. The rich who served as the hosts presented phrases of hope. The next section describes the governance of mangupa is started with the opening of hata pangupa by the rich people to hata pangupa, the answer from the bride.

The advise sentences of mangupa which are transcribed in the form of mangupa text are then analyzed and grouped into four: 1) mangupa text using the name of Allah SWT, 2) mangupa text of prayer and hope, 3) mangupa text of hope, 4) mangupa text with philosophical Angkola custom. 


\section{a. Mangupa text using the Name of Allah SWT}

This mangupa tradition implies a deep sense of faith in every community of Angkola to Allah SWT, to the achievement of wishes and expectations. It is emphasized in the sentences of the opening text of mangupa advice. The sentence of praise to Allah SWT is a thanksgiving given by suhut sapanggadongan (the host of the family) as a love and to Allah with the sentence: a) Bismillahirrahmanirrahim which means "In the name of Allah the Most Merciful and Most Beneficent", b) Alhamdulillahirobbil'alamin means "Praise to Allah exciting all nature", c) Puji syukur kita ucapkan kehadirat Allah SWT which means "Praise our thanks to the presence of Allah SWT", d) Gratitude, alhamdulillah hita ucapkon tu hadirat Allah SWT which means "Thanks to God praise to Allah we say into the presence of Allah SWT".

It is conveyed with the sentences: a) Shalawat dohot salam tu Nabitta Muhammad SAW which means: shalawat and congratulations to the Prophet Muhammad, b) Juga shalawat beriring salam untuk Nabi junjungan kita Muhammad saw agar kita mendapatkan syafa'atnya di hari kelak nanti which means "And also shalawat and congratulations to the Prophet Muhammad as our lover so that we get intercede in the next day later".

\section{b. Mangupa text of prayer and hope}

The substantial tradition of mangupa is the prayers and wishes that are conveyed to the bride in the form of living married life advice from the natolu dalihan customs and the whole family. The advice sentences of mangupa can be t classified into: a) healthy prayer and hope, b) easy prayer and hope of sustenance and enterprising, c) strong prayers and obedience in worship.

a) Prayer and Healthy Hope

The mangupa advice as the prayer and hope: Mudah-mudahan annon dilambung nadiparrasokionon sai sehat-sehat ma which means: "It is hopefully be healthy". The confirmation sentences are delivered by suhut sipanggadongan which indicated that other people also hope we are healthy family. The sentence is reinforced by bride's grandmother (ompung) with the advice sentence Oppung sehat-sehat ma hita which means "Our grandson must be healthy". Then re-affirmed with Hahorasan dohot which means "Keep the health".

The mother conveys to the bride as the mother's love and affection to her child and son in the mangupa text ...onpe nian tu ginjang ni ari sai horas ma hita sude sapanggadongan which means: "This is until later hopefully healthy all the family and ...". The meaning of the mangupa text conveyed by the grandmother to the bride at the mangupa ceremony outlines the intention that the health starts from today until the next day are in good health.

b) Prayer with the Hope Easy to Have Sustenance and Work Hard

The advice given by the customary leaders of $n a$ tolu to the two brides try to find a lawful sustenance in the advice Murah rasoki which means: "Easy to have sustenance. It is reaffirmed with the advice such as: Dilehen Tuhan ma rasoki na halal which means "Hopefully, the halal sustenance will be given by Allah. Work hard as in the pangupa Jadi indahanon, indahan nadi timba do goarnaon hita namanjalani kehidupan on harus bisa banting tulang. Banting tulang untuk mencari ..kehidupan on indahan nadi timbal doon dipayakkonon di bulung ujung tolu sada dua tolu which means "So this rice, rice that timba name, we who live this life should be slam bones. Banting bones for life."

The advice to be diligent and enterprising is conveyed by raja panusunan bulung Dohot mambaen rasoki...which means "to get sustenance" and reaffirmed with Sadoa mahita aso ronian rasoki anak dohot parumaen which means "One prayer for the sustenance of the child and the son-in-law". Then it is closed with Momo paccarion aso which means "Easy to get the livelihood". 
c) Prayer of Worship and Blessing

The traditional of mangupa begins with praise sentences on the opening and closing remarks as a form of obedience to Allah SWT, the sentences: a) Bismillahirrahmanirrahim which means "In the name of Allah the Most Merciful and Most Beneficent", b) Alhamdulillahirobbil'alamin which means "Praise to Allah", c) Puji syukur kita ucapkan kehadirat Allah SWT which means "Praise our thanks to the presence of Allah Almighty" d) Syukur, alhamdulillah hita ucapkon tu hadirat Allah SWT which means "Thanksgiving to God we say into the presence of God SWT."

It is conveyed with Borkat nia" which means "And blessings". Then the sentence is reinforced with Mudah-mudahan attong borkat di tonga arion which means "Hopefully blessings in the middle of today."

\section{c. Mangupa as Hope}

The mangupa tradition of Angkola custom is conveyed by the traditional leaders of datihan natolu then transcribed and classified into: a) loving mother, b) mutual covering, c) being mature.

a) Love mother

The tradition of mangupa as the expectations every traditional leaders, every child loves mothers who have given birth, because the services of a mother cannot be avenged. Mangupa as an expression of gratitude and hope that both the bride and groom love the second mother of the bride, the sentence of advice is the hope that the bride and groom love it with Satahi hamu holong rohamunu diinatta harana ia nasabariba tangan nama ia on pettong wich means "Love your mother because our mother is alone now."

The big hope of all traditional and parent leaders to the children and children in law order to receive all the advice conveyed with the mangupa as in Sanolion masosonang roha niumatta, tarsongonimada which means "Once upon a time to be happy our mothers are happy, just like that."

b) Mutual Covering

What the advice sentence that is meant by covering each other is to keep the bride and groom able to keep things that only become household secrets. This is conveyed by the adat leader to the bride with a sentence like Marsitutup-tutupkan kamu which means "You cover each other." The advice of hope to the bride is to be the same close each other-covering the household problem.

c) Being Mature

The advice conveyed by the traditional figure is Semakin dewasa tungganekkudison anggo hami majolo madung do hai tanda ho tunggane, muda diligi tu jae diligi tu julu namargoar naposo arakku ho dope peringkat pertama namarguar tobang niroha... nahuboto $d a$ ! which means "If it viewed to and fro the name of young people in my opinion still you again ranked first whose name mature heart. What I know." So according to the observation of the customary leaders to the brides are mature enough to behave so far, so far the groom has grown quite mature than their friends.

d) Mangupa to be Social

On the advice of traditional mangupa which the content is to keep a good relation with family and society is manifested in the advice like: Bisa seperti garam. Jadi, aso berbaur kepada semua masyarakat berbaur ia. Jadi pelengkap, penyedap tanpa garam. Tanpa si Kelli anak ni si....hurang padena imada giotna ate, tai harani si Kelli napade Ritonga i dison ninna ulang songoni. Tapi ini dimanfaatkan kepada yang positif sangape namaso sonnarikan ah napodo ro si Kelli bah na sai tarbahason anggo nadison si Kelli nahuboto cari kawan ninna. Anggo na dison si Kelli ... nadapot ujungna. The meaning is "Live like salt, Be, you 
both are like this salt. If the bridegroom in Ritonga's extended family is not yet here the Keli is not complete this meeting, if not here the boru Nasution this meeting is not complete, so that in all forms of society, in the family, at work if we are not there less meaning of a job.

e) Mangupa for harmony and peace

The tradition of mangupa gives a look to the harmonious and peaceful life of married life. The pangupa sentences: Rumah tangga bahagia, rumaha tangga sakinah, rumah tangga yang diridhoi Allah SWT means words of advice, good family, happy households, sakinah households blessed by Allah SWT. Then examples like anduri on the mangupa text Kemudian makna dari pada anduri tampi itu adalah untuk membersihkan yang kotor tinggal sitinggal-tinggal yang bersih. Membuang yang tidak bersih-bersih means mangupa is to give an example on the function anduri (wide plate) is to clean the dirty, stay only clean. Throw away the unclean. Then mengkipas hula and teman kan to clean the bota of paddy is to clean the heart, and self.

\section{Conclusion}

Based on the description of the data, some conclusions can be taken as follows: the Angkola traditional wedding ceremony is the top show of mangupa tradition by conveying advice to the bride as a life guidance of household. The delivery of advice submitted in sequence starting from: 1) The rich, 2) Suhut sihabolonan starts from mothers and men, 3) kahanggi, 4) anak boru, mora, and raja panusunan bulung as the closing and read the letter of situmbaga holing through the materials of Angkola mangupa custom at the level of manonga. The mangupa advice is grouped intop four, 1) mangupa text using the name of Allah SWT, 2) mangupa text of prayer and hope, 3) mangupa text of hope, and 4) mangupa text with philosophical Angkola custom.

The mangupa tradition has a philosophical meaning that has messages by using pangupa materials that are interpreted the nonliteral symbol so that the brides and the audiences are able to interpret the message as a philosophical symbol that serves as a holistic culture as a guide for the life of: sangap, hamoraon, hagabeon. The traditional mangupa performance has become part of Angkola's identity. The local wisdom describes: a) the wisdom of social solidarity, b) the wisdom of mutual cooperation, the wisdom of the relationship to Allah SWT (vertical), c) the wisdom of the relationship to the community (horizontal), d) the wisdom of the relationship with nature, e) the wisdom in language, $f$ ) the wisdom as a cultural memory, and $\mathrm{g}$ ) the wisdom of a gender admiration.

\section{References}

Amri, K. Y.2011. Tradisi Lisan Upacara Perkawinan Adat Tapanuli Selatan: Pemahaman Leksikon Remaja di Padangsidimpuan. Sumatera Utara: Pascasarjana, Repository Universitas Sumatera Utara.

Amri, K. Y.2017. Tradisi Mangupa Horja Godang Upacara Perkawinan Adat Angkola. Disertasi. Sumatera Utara: FIB, Repository Universitas Sumatera Utara.

Amri, K. Y. 2018. Mangupa; an Oral Tradition of Angkola Community. Budapest International Research and Critics Institute-Journal (BIRCI-Journal) (1): 51-61.

Bungin, B. 2006. Penelitian Kualitatif: Komunikasi, Ekonomi, Kebijakan Publik, dan Ilmu Sosial Lainnya. Jakarta: Kencana.

De Saussure, Ferdinand. 1969. Cours de Linguistique Generale. Paris: Payot. 
Dijk, V.TA.1977. Text and Context: Explorations in the Semantics and Pragmatics of Discourse. Longmans Linguistics Library. Longman, London.Duranti, A. 2001. Linguistic Anthropology: A Reader. Massachussets: Blackwell Publishers.

Duranti, A.2001. "Linguistic Anthropology". Massachusetts: Blackwell.

Duranti, A. Linguistic Anthropology. Cambridge: Cambridge University Press.

Foley, William, A. 1997. Anthropological Linguistics: An Introduction. Oxford: Blackwell.

Foley, Miles, J. (Ed) 1986. Oral Tradition in Literature: Interpretation in Context. Columbia: University of Missouri Press.

Finnegan, Ruth.1992. Oral Traditions and The Verbal Arts: A Guide to Research Practices. New York: Routledge.

Harahap, P. M.1993. Horja: Adat Istiadat Dalihan Natolu, Jakarta: Parsadaan Marga Harahap Dohot Anak Boruna.

Harahap, R. B. "Poda-podda Ni Adat Horja Godang/ Bolon/ Siluluton/ Siriaon."

Hasil Musyawarah Lembaga Adat dan Budaya.24-26 Oktober.1996, "Adat Budaya AngkolaSipirok-Haruaya Mardomu Bulung Napa-napa Ni Sibualbuali”.

Hidayat, B.2004. Tema-tema Psikologis dalam tradisi Mangupa pada pasangan pernikahan pemula dalam masyarakat perantau Tapanuli Selatan di Pekanbaru. Yogyakarta: Program Studi Psikologi FPSB UII.

Hoed., and Benny H. 2008. Semiotik dan Dinamika Sosial Budaya. Depok: Fakultas Ilmu Pengetahuan Budaya Univesitas Indonesia.

Imran, Muammar, Jauharah, Aziz, A. T., Darmawi, and Hadianti.2019. Tawkil Traditions in the Implementation of Marriage Contract in Aceh, Indonesia. Budapest International Research and Critics Institute-Journal (BIRCI-Journal) (2): 210-218.

Marpaung, M.1969. Djop ni Roha Pardomuan (Paradaton Tapanuli Selatan) Padang Sidempuan: Pustaka Timur.

Martozet, Nurwani.2019. Sentimental Values in Tor-Tor Parsiarabu in Tomok Toba Samosir Village. Budapest International Research and Critics Institute-Journal (BIRCI-Journal) (2): 167-171.

Nasution, P. H.2005. Adat Budaya Mandailing: dalam Tantangan Zaman. Medan: Forkala.

Nort, W.1990.1995. Handbook of Semiotics. Bloomington/ Indianapolis: Indiana University Press.

Olrik, Axel.1992. Principles for Traditions Narrative Research. Blomington: Indiana University Press.

Ong, Walter J.2007. Orality and Lteracy. New York: Methuen and Co. Ld.

Parrot, Nancy.2000. Linguistic Anthropology Second Edition. Texas Tech University: Hartcourt College Publishers.

Pudentia.2003. Antologi Prosa Rakyat Melayu Indonesia. Jakarta: Pusat Bahasa.

Ritonga, Parlaungan, and Azhar, R.2002. Sistem Pertuturan Masyarakat Tapanuli Selatan, Medan: Yandira Agung.

Saragih, Amrin.2011. Semiotik Bahasa: Tanda, Penanda, Petanda dalam Bahasa. Bahan Ajar Perkuliahan Semiotik Program Studi Linguistik USU Medan.

Sibarani, Robert.2012. Kearifan Lokal (Hakikat, Peran, dan Metode Tradisi Lisan). Jakarta: Asosiasi Tradisi Lisan (ATL).

Siregar B. G., Gelar H., and Tinggibarani, S.2009. Tutur Poda, (Naskah stensilan)

Siregar B. G., Gelar H., and Tinggibarani, S.2007. Burangir Barita, (Naskah stensilan)

Siregar B. G., Gelar H., and Tinggibarani, S.1980. Horja Godang Magupa Di Na Haroan Boru, (Naskah stensilan)

Siregar B. G., Gelar H., and Tinggibarani, S.1984. Surat Situmbaga Holing Adat BatakSipirok- Padang Bolak- Barumun- Mandailing- Batang Natal- Natal. (Naskah stensilan) 
Spradley, James P.1980. Doing Participants Observation. Participants Observation. New York: Holt Rinehart and Winston.

Strauss, L., Claude. 1972. Structural Anthropollogy. Great Britain:Penguin Books. Tim Penyusun.2006. "Khazanah Adat Budaya Tapanuli Selatan".

Tutik, Triwulan, T., and Trianto, 2008. Dimensi Transedental dan Transformasi Sosial Budaya. Jakarta: Lintas Pustaka. 